\title{
Basidiomycetous Fungi in Mt. Palay-palay Protected Landscape, Luzon Island, Philippines
}

\author{
LEA P. ANGELES
}

ORCID No. 0000-0003-1148-9887

angeles.lp@gmail.com

San Juan de Dios Educational Foundation, Inc.,

Pasay City, Philippines

\section{EDUARDO JIMMY M. ARMA}

ORCID No. 0000-0001-5163-3009

arma.ejm@gmail.com

University of Perpetual Help-Dalta System,

Las Piñas City, Philippines

CHERRYL W. BASACA

ORCID No. 0000-0002-0113-3732

basaca.cw@gmail.com

Laguna State Polytechnic University,

Los Baños, Laguna, Philippines

\section{HAYDEE EVANGELINE H. BISCOCHO}

ORCID No. 0000-0001-904-301X

biscocho.he@gmail.com

De La Salle University - Dasmariñas,

Cavite, Philippines

\section{ARIZALDO E. CASTRO}

ORCID No. 0000-0001-6929-5407

castro.ae@gmail.com

De La Salle University - Dasmariñas,

Cavite, Philippines 
SHERINE M. CRUZATE

ORCID No. 0000-0003-0205-0450

cruzate.sm@gmail.com

Cavite State University - Indang,

Cavite, Philippines

RYAN JOHN G. GARCIA

ORCID No. 0000-0002-7448-8454

garcia.rg@gmail.com

Mirriam College,

Quezon City, Philippines

\section{LLYRHA MAE E. MAGHARI}

ORCID No. 0000-0002-9777-0217

maghari.lme@gmail.com

De La Salle Health Sciences Institute, Dasmariñas,

Cavite, Philippines

\section{ROSAHLE S. PAGADORA}

ORCID No. 0000-0002-2677-1001

pagadora.rs@gmail.com

Fiat Lux Academe, Dasmariñas,

Cavite, Philippines

\section{EDWIN R. TADIOSA}

ORCID No. 0000-0002-0268-692X

ertadiosa@yahoo.com

College of Science and Computer Studies - Graduate Department,

De La Salle University and

Philippine National Herbarium, Botany Division,

National Museum of the Philippines 


\begin{abstract}
Basidiomycetous fungi are ubiquitous organism thriving mostly in forest ecosystem. A study of these group of fungi was conducted at Mt. Palaypalay Protected Landscape (MPPL) in Southern Luzon, Philippines. This protected landscape was categorized by National Integrated Protected Areas System as one of the priority areas for biodiversity conservation. This study aimed to document the existence of Basidiomycetes in the Landscape. Collection and photo-documentations of fungi were done during the months of December 2014 to June 2015. Fungal sampling was done using Transect Line (TL) with a combination of quadrat and opportunistic sampling methods. Three transect lines, one kilometer each was laid out from baseline of 100 masl up to 500 masl. Ten quadrats of $15 \mathrm{~m} \times 20 \mathrm{~m}$ with an interval of $250 \mathrm{~m}$ were established for each TL. Fleshy and woody Basidiomycetous species were collected, identified, and characterized based on established dichotomous keys. Of the 434 specimens collected, there were 24 families, 37 genera, and 41 species identified. The Landscape is currently experiencing some degree of anthropogenic disturbances such as minor forest products gathering, slash-and-burn farming, and quarrying. Fungal diversity research efforts need to be encouraged to evaluate the effects of these human disruptions on the ecology of the Landscape.
\end{abstract}

Keywords: Basidiomycetous fungi, forest ecosystems, Mt. Palaypalay, Luzon Island, Philippines

\title{
INTRODUCTION
}

Fungi are organisms which are grouped together since they possess chitin in their cell walls, and they nourish themselves by digesting organic matter first then subsequently ingesting it. Even most fungi resemble plants in appearance, a distinct difference between the two groups is that the former nourish themselves by absorbing nutrients from dead or living organic matter which are byproducts of the enzymatic degradation process they initiate by means of secreted exoenzymes. The following heterotrophy by absorption, fungal species cater to one of the most important ecological processes, nutrient recycling of organic matter (Taylor et al. 2006).

One apparent member of this kingdom that utilizes a variety of substrates are the Basidiomycota. Basidiomycota is a sister phylum to the monophyletic 
Ascomycota and is morphologically observed as filamentous fungi that can reproduce asexually via the production of specialized club-shaped cells called basidia. These basidia normally contain four spores. Basidiomycota includes mushrooms, puffballs, earth stars, smuts, rusts, jelly fungi, bracket fungi among others (Swann and Hibbett 2007).

Mt. Palaypalay Protected Landscape (MPPPL) is a 4000-hectare mountain range located in the borders of Nasugbu, Batangas, and Ternate, Cavite and situated $14^{0} 1658.43^{\prime \prime} \mathrm{N}$ latitude and 120 $0^{\circ} 1^{\prime} 49.22^{\prime \prime}$ E longitude. (Figure 1). The MPPPL has been a frequent study site for the assessment of plant and animal diversity (Luyon and Salibay 2007). This mountain range is teeming with various species of organisms but seems to be threatened as of today. This protected landscape experiencing some anthropogenic activities carried out within its vicinities such as charcoal manufacturing, farming, cattle grazing, collection of minor forest products, quarrying, and illegal cutting of trees particularly during the 1960s (Green for Life: One Million Trees and Beyond 2009). The landscape is a favorite destination for local hikers and campers and was categorized by NIPAS as Protected Landscape under Presidential Decree, Proclamation No. 1315 on June 27, 2007 in order to protected and preserve its biodiversity.

Currently, one group of organisms whose diversity in MPPPL has not been thoroughly studied are the fungi. In this study, fungal species belonging to Basidiomycota were identified and characterized to provide base line preliminary information regarding the diversity of this fungal group in Mt. Palaypalay Protected Landscape. They are known to have a significant role in the nutrient cycling of the forest ecosystem (Klemm 2005). Typically, they grow on decaying plants or animals, soil, leaf litter, rotting logs or compost heaps or manure (Reyes et al. 2009). 

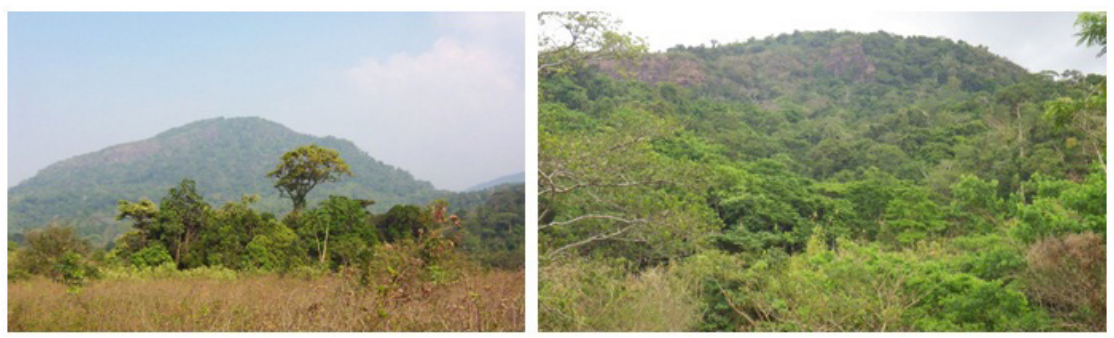

Plate 1. The views of Mt. Palaypalay Protected Landscape from the highway near Puerto Azul.

\section{OBJECTIVES OF THE STUDY}

This research study was done to account the basidiomycetous fungi present in Mt. Palaypalay Protected Landscape. Specifically this research aimed to: (1) identify basidiomycetous fungi based on physical and anatomical features, (2) provide listing of this group of fungi present at MPPPL, and (3) determine the economic and ecological importance of this group of organisms in MPPPL ecosystem.

\section{MATERIALS AND METHODS}

\section{Description of Study Site}

The research study was carried out in Mt. Palay-palay Protected Landscape in Ternate, Cavite, which lies between $14^{\circ} 13.904^{\prime} \mathrm{N}$ latitude and $120^{\circ} 39.439^{\prime} \mathrm{E}$ longitude (Etrex GPS Device, Garmin). The area has two pronounced seasons, dry from November to April, and wet during the rest of the year. Weather is humid most of the year except December and March when there is characteristic dryness of the locality. Mt. Palay-palay is one of the three major peaks in the Landscape. Other peaks include Mataas na Gulod and Pico de Loro. The collection site was Mt. Palaypalay, which is the largest and best-conserved forest among the three.

The forested areas of the mountain boast a plethora of vegetation types ranging from sub-tropical to tropical. Because of its diverse topography and different climatic factors, the study site can be considered as highly diverse (Figure 2). 


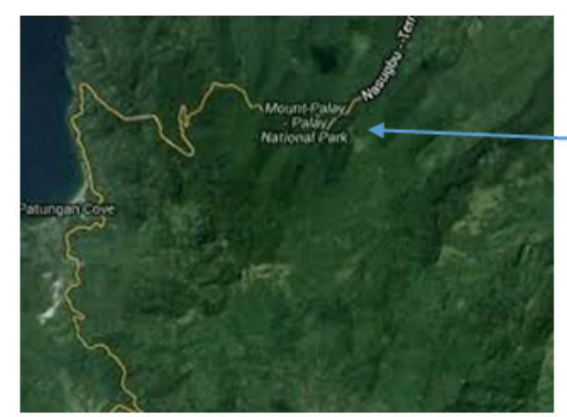

Ibc.lynxeds.com

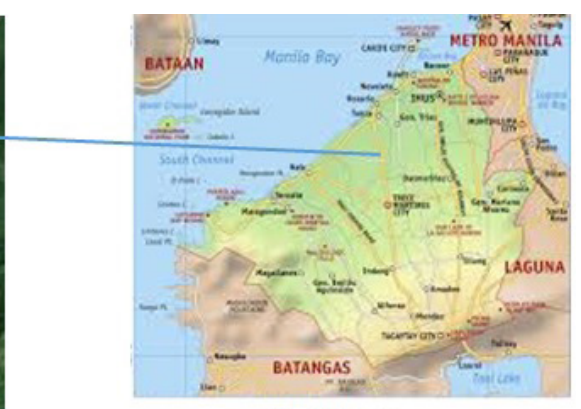

tl.wikipedia.org

Figure 2. Map of Cavite showing the study area, Mt. Palay-palay National Park/ Protected Landscape.

\section{Field Sampling of Basidiomycetous Fungi}

Field sampling was completed using three transect lines (TL) with ten quadrats, $15 \mathrm{~m} \times 20 \mathrm{~m}$ with an interval of $250 \mathrm{~m}$ on each quadrat. Transect line was laid starting at $100 \mathrm{~m}$ above sea level upward to the peak of 500 masl. A total of 30 quadrats were laid out in the study areas. The combination of quadrat method and opportunistic and or purposive sampling methods were employed in the study areas. All macroscopic basidiomycetous fungi found inside and outside the quadrat were photographed in their natural habitat, collected, identified and classified.

Fungal host, color, shape, the size of the fruiting bodies, prevailing temperature and humidity in the area at the time of collection and Global Positioning System (GPS) coordinates were recorded during the time of collection and documentation. Macroscopic fungi inhabiting the soil and ground litter were dug using a trowel, and, for those attached to tree branches or barks, were gathered using bolo and knife.

\section{Specimen Collection}

Field collection of specimen and data were done during rainy and summer season. Specimens were photographed in the field (as they occur in their natural habitats) and all important morphological characters including the substrata were noted.

During collection, fragile and fleshy specimens were not mixed with woody ones. The woody specimens were removed with the use of bolo together with the 
wood tissues while shovel was used in collecting the fleshy ones (Tadiosa et al. 2011).

\section{Specimen Preservation}

Collected specimens were preserved by mechanical oven drying and alcohol immersion. Field collection numbers were given to each and every specimen, and they were stored in the Natural History Collections of the Biological Sciences Department of De La Salle University-Dasmariñas for future reference.

The woody and bracket specimens were wrapped in newspaper while fragile and fleshy specimens were directly placed in wide-mouthed jars, together with the pertinent data and all other notes useful for taxonomic identification. They were dried and subsequently fumigated to kill insects, particularly the destructive larvae.

Upon reaching the laboratory, woody and fleshy specimens were segregated from one another. After additional notes had been taken, the woody specimens underwent drying as preservation and fleshy ones were immersed in $70 \%$ denatured alcohol as a preservative. The length of the drying period of all specimens collected varied depending upon the nature of the specimens and the prevailing temperature and the relative humidity of the air during collection (Karun and Sridhar 2013; Tadiosa et al. 2011).

\section{Characterization of Collected Fungal Specimens}

The following criteria were used to describe and identify the collected fungal specimens:

a. cap or pileus- size $(\mathrm{cm})$, shape, color and color changes (upper and lower surface), margin, and firmness of basidiocarp;

b. gills or lamellae-attachment to the stipe, thickness, forking, color and color changes, and orientation of hyphae in the inner gills;

c. stipe or stalk- size $(\mathrm{cm})$, diameter $(\mathrm{cm})$, attachment or position, shape, and firmness;

d. presence or absence of cystidia, basidia, and basidioles;

e. presence or absence of sterigmata;

f. mycelium-if visible, color when still attached to the basal stipe and the roots; and,

g. hyphae- relative size, presence or absence of septation and clamp connection

h. habitat (substrate) and edibility. 


\section{Taxonomic Identification and Classification}

Identification was facilitated using standard dichotomous keys such as those prepared by Arora (1986); Smith et al. (1988) and Hood (1992) together with colored and representative photographs from the books of Koon (1990), McKnight (1999), Quimio (1988 and 2001), and Laessoe (1998). Confirmation of initial identities of the specimens was further done by consulting with the expert from the Botany Division of the National Museum of the Philippines. After identification, collected specimens were listed according to their respective families.

\section{RESULTS AND DISCUSSION}

\section{Taxonomy of Collected Basidiomycetous Fungi}

Field sampling of Basidiomycetous fungi had resulted in the identification of 24 families (Table 1), 37 genera, and 41 species with a total of 434 individuals. The dominant group is the Polyporaceae with 6 out of 41 species identified or $14 \%$ of the species collected. Coriolaceae and Tricholomataceae with four species each are next in abundance with roughly $10 \%$ of the species collected, and the third is Ganodermataceae having 3 species or $7 \%$ of the species collected. The rest of the families have less than 3 species each. Basidiomycetous fungi were found growing mostly on rotten trunks, branches, and stumps of dying trees. 
Table 1. The Taxa and Its Substrates where these Fungi Grow Including the Elevation where these are found as well as Growth Habit

\begin{tabular}{|c|c|c|c|}
\hline TAXA & HOST/ SUBSTRATE & $\begin{array}{l}\text { ELEVATION } \\
\text { (masl) }\end{array}$ & $\begin{array}{l}\text { GROWTH } \\
\text { HABIT }\end{array}$ \\
\hline \multicolumn{4}{|l|}{ AGARICACEAE } \\
\hline Lepiota cristata & soil, along the trail & 242 & solitary \\
\hline \multicolumn{4}{|l|}{ AURICULARIACEAE } \\
\hline Auricularia auricula & $\begin{array}{c}\text { on rotten trunk of Psidium } \\
\text { guajava }\end{array}$ & 256 & gregarious \\
\hline Auricularia polytricha & $\begin{array}{l}\text { on rotten branch of } \\
\text { Bauhinia purpurea }\end{array}$ & 238 & gregarious \\
\hline \multicolumn{4}{|l|}{ CANTHARELLACEAE } \\
\hline Cantharellus infundibuliformis & $\begin{array}{c}\text { on rotten stump of Gmelina } \\
\text { arborea }\end{array}$ & 254 & gregarious \\
\hline \multicolumn{4}{|l|}{ COPRINACEAE } \\
\hline Coprinus disseminatus & soil, grassland & 235 & gregarious \\
\hline Coprinus plicatilis & soil, grassland & 246 & gregarious \\
\hline \multicolumn{4}{|l|}{ CORIOLACEAE } \\
\hline Hexagonia apiaria & $\begin{array}{l}\text { on rotten branch of Vitex } \\
\text { parviflora }\end{array}$ & 458 & $\begin{array}{c}\text { solitary to } \\
\text { gregarious ( } 3-5 \text { in } \\
\text { a group }\end{array}$ \\
\hline Hexagonia tenuis & $\begin{array}{c}\text { on rotten branch of } \\
\text { Leucaena leucocephala }\end{array}$ & 478 & gregarious \\
\hline Lenzites repanda & $\begin{array}{c}\text { on rotten branch of } \\
\text { Dillenia philippinensis }\end{array}$ & 494 & $\begin{array}{c}\text { solitary to } \\
\text { gregarious ( } 3-5 \text { in } \\
\text { a group) }\end{array}$ \\
\hline Trametes corrugate & $\begin{array}{c}\text { on rotten branch of } \\
\text { Syzygium subcaudatum }\end{array}$ & 492 & $\begin{array}{c}\text { solitary to } \\
\text { gregarious (4-6 in } \\
\text { a group) }\end{array}$ \\
\hline \multicolumn{4}{|l|}{ CORTINARIACEAE } \\
\hline Cortinarius callisteus & soil, along the trail & 345 & solitary \\
\hline \multicolumn{4}{|l|}{ CREPIDOTACEAE } \\
\hline Crepidotus mollis & $\begin{array}{l}\text { on rotten branch of } \\
\text { Canarium asperum }\end{array}$ & 465 & gregarious \\
\hline \multicolumn{4}{|l|}{ DACRYOMYCETACEAE } \\
\hline Dacryopinax spathularia & $\begin{array}{l}\text { on rotten trunk of } \\
\text { Pterocarpus indicus }\end{array}$ & 458 & gregarious \\
\hline \multicolumn{4}{|l|}{ GANODERMATACEAE } \\
\hline Amauroderma rugosum & $\begin{array}{c}\text { on rotten roots of } \\
\text { Diospyros pilosanthera }\end{array}$ & 365 & solitary \\
\hline Ganoderma applanatum & $\begin{array}{c}\text { on rotten stump of } \\
\text { Leucaena leucocephala }\end{array}$ & 348 & $\begin{array}{c}\text { solitary to } \\
\text { gregarious (3-5 in } \\
\text { a group) }\end{array}$ \\
\hline Ganoderma lucidum & $\begin{array}{l}\text { on rotten stump of } \\
\text { Dracontomelon dao }\end{array}$ & 412 & solitary \\
\hline \multicolumn{4}{|l|}{ GEASTRACEAE } \\
\hline Geastrum saccatum & soil, along the trail & 242 & gregarious \\
\hline \multicolumn{4}{|l|}{ HYGROPHORACEAE } \\
\hline Hygrophorus pratensis & soil, thickets & 238 & gregarious \\
\hline \multicolumn{4}{|l|}{ HYMENOCHAETACEAE } \\
\hline Hymenochaete rubiginosa & $\begin{array}{c}\text { on rotten trunk of Wrightia } \\
\text { pubescens }\end{array}$ & 346 & $\begin{array}{c}\text { solitary to } \\
\text { gregarious (3-5 in } \\
\text { a group) }\end{array}$ \\
\hline Phellinus gilvus & $\begin{array}{c}\text { on rotten branch of } \\
\text { Swietenia macrophylla }\end{array}$ & 354 & solitary \\
\hline
\end{tabular}




\begin{tabular}{|c|c|c|c|}
\hline MARASMIACEAE & & & \\
\hline Marasmius rotula & $\begin{array}{l}\text { on rotten roots of } \\
\text { Antidesma bunius }\end{array}$ & 376 & gregarious \\
\hline \multicolumn{4}{|l|}{ MYCENACEAE } \\
\hline Mycena galopus & soil, thickets & 465 & gregarious \\
\hline \multicolumn{4}{|l|}{ PLEUROTACEAE } \\
\hline Pleurotus ostreatus & $\begin{array}{c}\text { on rotten trunk of } \text { Aglaia } \\
s p .\end{array}$ & 478 & gregarious \\
\hline \multicolumn{4}{|l|}{ PLUTEACEAE } \\
\hline Volvariella volvacea & banana leaves & 450 & gregarious \\
\hline \multicolumn{4}{|l|}{ POLYPORACEAE } \\
\hline Daedalea ambigua & $\begin{array}{l}\text { on rotten branch of } \\
\text { Pterocarpus indicus }\end{array}$ & 486 & solitary \\
\hline Daedalea flavida & $\begin{array}{c}\text { on rotten branch of Vitex } \\
\text { parviflora }\end{array}$ & 493 & solitary \\
\hline Favolus reniformis & $\begin{array}{c}\text { on rotten branch of } \\
\text { Leucaena leucocephala }\end{array}$ & 345 & solitary \\
\hline Fomes gilvus & $\begin{array}{l}\text { on rotten stump of Shorea } \\
\text { guiso }\end{array}$ & 365 & solitary \\
\hline Microporus xanthopus & $\begin{array}{c}\text { on rotten stump of Cordia } \\
s p .\end{array}$ & 453 & $\begin{array}{c}\text { solitary to } \\
\text { gregarious (3-6 in } \\
\text { a group) }\end{array}$ \\
\hline Pycnoporus sanguineus & $\begin{array}{c}\text { on rotten branch of } \\
\text { Macaranga grandifolia }\end{array}$ & 465 & $\begin{array}{c}\text { solitary to } \\
\text { gregarious (3-5 in } \\
\text { a group) }\end{array}$ \\
\hline \multicolumn{4}{|l|}{ RUSSULACEAE } \\
\hline Lactarius piperatus & soil, grassland & 456 & solitary \\
\hline \multicolumn{4}{|l|}{ SCHIZOPHYLLACEAE } \\
\hline Schizophyllum commune & $\begin{array}{l}\text { on rotten branch of } \\
\text { Glochidion } s p \text {. }\end{array}$ & 246 & gregarious \\
\hline \multicolumn{4}{|l|}{ STEREACEAE } \\
\hline Stereum complicatum & $\begin{array}{c}\text { on rotten branch of } \\
\text { Antidesma sp. }\end{array}$ & 432 & $\begin{array}{c}\text { solitary to } \\
\text { gregarious (3-5 in } \\
\text { a group) }\end{array}$ \\
\hline Stereum sanguinolentum & $\begin{array}{c}\text { on rotten branch of } \\
\text { Myristica } s p .\end{array}$ & 476 & $\begin{array}{c}\text { solitary to } \\
\text { gregarious (4-6 in } \\
\text { a group) }\end{array}$ \\
\hline \multicolumn{4}{|l|}{ STROPHARIACEAE } \\
\hline Hypholoma fasciculare & soil, thickets & 465 & solitary \\
\hline \multicolumn{4}{|l|}{ THELEPHORACEAE } \\
\hline Thelephora terrestris & $\begin{array}{l}\text { on rotten roots of } \\
\text { Canarium sp. }\end{array}$ & 342 & gregarious \\
\hline \multicolumn{4}{|l|}{ TREMELLACEAE } \\
\hline Tremella fuciformis & $\begin{array}{c}\text { on rotten trunk Leucaena } \\
\text { leucocephala }\end{array}$ & 245 & gregarious \\
\hline \multicolumn{4}{|l|}{ TRICHOLOMATACEAE } \\
\hline Collybia maculate & soil, grassland & 346 & solitary \\
\hline Panus rudis & soil, grassland & 321 & $\begin{array}{c}\text { solitary to } \\
\text { gregarious (3-5 in } \\
\text { a group) }\end{array}$ \\
\hline Termitomyces striatus & soil, termite mound & 238 & gregarious \\
\hline Lentinus strigosus & soil, grassland & 265 & gregarious \\
\hline
\end{tabular}


Table 2. Basidiomycetous Fungal Families and Its Corresponding Number of Species Collected at MPPPL

\begin{tabular}{|c|c|}
\hline FUNGAL FAMILIES & NUMBER OF SPECIES \\
\hline Agaricaceae & 1 \\
\hline Auriculariaceae & 2 \\
\hline Cantharellaceae & 1 \\
\hline Coprinaceae & 2 \\
\hline Coriolaceae & 4 \\
\hline Cortinariaceae & 1 \\
\hline Crepidotaceae & 1 \\
\hline Dacryomycetaceae & 1 \\
\hline Ganodermataceae & 3 \\
\hline Geastraceae & 1 \\
\hline Hygrophoraceae & 1 \\
\hline Hymenochaetaceae & 2 \\
\hline Marasmiaceae & 1 \\
\hline Mycenaceae & 1 \\
\hline Pleurotaceae & 1 \\
\hline Pluteaceae & 1 \\
\hline Polyporaceae & 6 \\
\hline Russulaceae & 1 \\
\hline Schizophyllaceae & 1 \\
\hline Stereaceae & 2 \\
\hline Strophariaceae & 1 \\
\hline Thelephoraceae & 1 \\
\hline Tremellaceae & 1 \\
\hline Tricholomataceae & 4 \\
\hline Number of Families $=24$ & Number of Species $=41$ \\
\hline
\end{tabular}




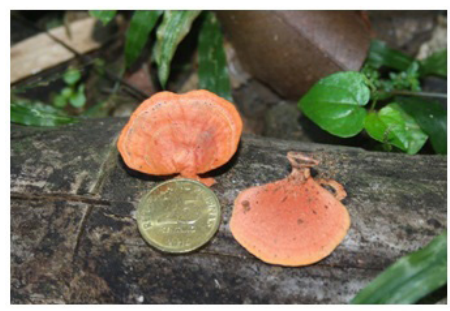

Pycnoporus sanguineus (Fr.) Murr.

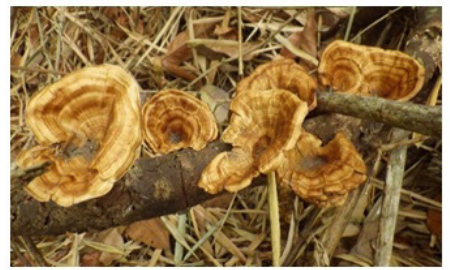

Microporus xanthopus (Fr.) Kuntze

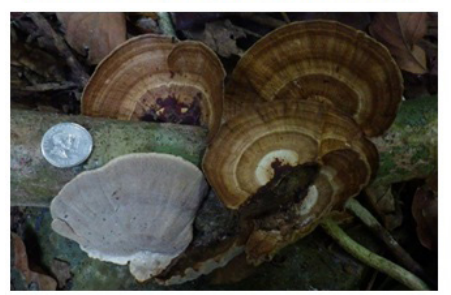

Hexagonia tenuis (Hook.) Fr.

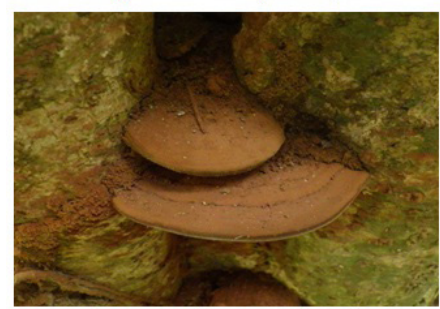

Ganoderma applanatum (Pers.) Pat.

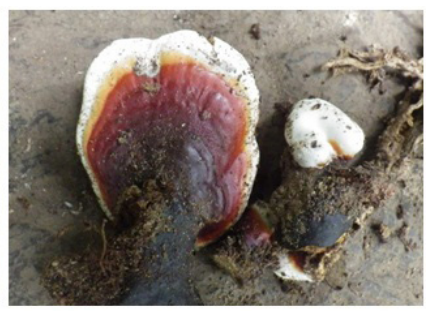

Ganoderma lucidum (Leys.) Karst.

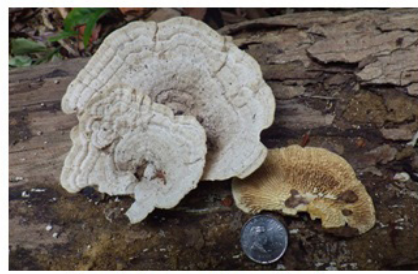

Daedalea ambigua Berk.

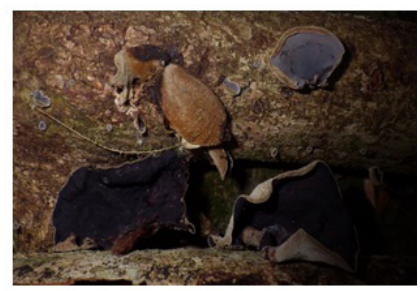

Auricularia polytricha (Mont.) Sacc.

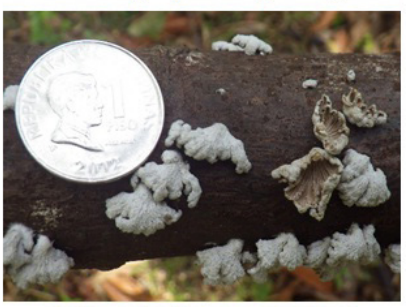

Schizophyllum commune Fr.

Plate 1. Some of the Basidiomycetous Fungi Documented at Mt. Palaypalay Protected Landscape. 


\section{Suitability of Growth and Factors Affecting the Diversity of Fungi in MPPPL Area}

The interplay between factors such as wind speed, temperature, humidity, and faunal statistics is responsible for the diversity of Basidiomycetous fungal specimens collected at the study site. As organisms that rely heavily on spore dispersal and high moisture content of the environment, it is logical to think that these species will thrive in areas that are always almost humid. Forested areas in Southern Luzon such as MPPPL is itself a suitable environment for the reproduction of these organisms.

Wind speed assists in the rapid dispersal of spores were bringing them to other places that can support their development to adulthood. Season of collection directly influences the number of fungal organisms that can be collected and observed. During the dry season (December to May), where humidity is low and it is usually hot, diversity of Basidiomycetous fungi tend to decrease as compared to the wet season where enough moisture is received by substrate tree tissues and soil to support the proliferation and development of varying Basidiomycetes and the plethora of fruiting bodies they have. The variety of insects feeding on fungal fruiting bodies also dictates the kinds of Basidiomycetes that can be surveyed for a particular period.

\section{CONCLUSIONS AND RECOMMENDATIONS}

Albeit with limited time and the season during collection which is not so ideal for specimen collection, the unique diversity of Basidiomycetous fungi in MPPPL was still observed and accounted for. After identifying the collected specimens and providing a listing of it, the results of this study indicate that MPPPL is one of the species-rich areas of the country teeming with many organisms. Based on our observation, these fungi are great decomposers in the forest ecosystem. These fungi are largely responsible for decay in living trees, rotten branches and trunk, other wood in service and valuable standing timbers. Other species have known for its edibility and can be a source of food and medicine.

Therefore, it is recommended that continuous researches be done to acquire more data establishing the seasonal fungal biodiversity profile of the study site which is very important in devising conservation measures to protect and preserve the richness of MPPPL. 


\section{ACKNOWLEDGMENTS}

The authors would like to express their heartfelt appreciation to the following individuals who made this study possible: Dr. Johnny Ching, Dean of College of Science and Computer Studies (DLSU-D), Prof. Cherry Cuevas, DLSU-D and DLSU-D representative to PAMB-MPPMGPL, Provincial Environment and Natural Resources Officer and concurrent Protected Area Superintendent Engr. Rolinio Z. Pozas for allowing the group to study fungi, Ricky Morales who served as guide of the group, Kuya Digoy(+) and Manang Fely who assisted the group while in the area, and to the authors family who supported their fieldworks.

\section{LITERATURE CITED}

Alexopoulous CJ, Mims CW. 1979. Introductory Mycology. Third Edition, John Wiley \& Sons. New York.

CALABARZON Regional Physical Framework. 2008. Region IV -A (CALABARZON) REGIONAL PHYSICAL FRAMEWORK PLAN 2004-2030 (Volume 2 - Physical and Socio-Economic Profile and Situational Analysis) Philippine National Economic and Development Authority Regional Office IV-A (CALABARZON) Printed in Quezon City, Philippines page 44.

Chang ST, Buswell JA. 1996. Mushroom nutraceuticals. World Journal Microbiology Biotechnology, 12: $473-6$

CLIMATE OF THE PHILIPPINES. 2014. http://kidlat.pagasa.dost.gov.ph/cab /climate.htm retrieved on January 2014.

Cooke RC, Rayner ADM. 1984. Ecology of Saprotrophic Fungi. Longman, London.

De leon AM, Luangsa - Saed JJD, Karunarathna SC, Hyde KD, Reyes RG, dela Cruz TEE. 2013. Species listing, distribution, and molecular identification of macrofungi in six Aeta tribal communities in Central Luzon, Philippines. Mycosphere. 4, (3):478 - 494. doi10.5943/mycosphere/4/3/4. 
Ecoutourism in CALABARZON. 2014. Data retrieved from http://pmd.6te. net/ecotourism-calabarzon/Protected_PalayPalay.html on July 14, 2014.

Green for Life: One Million Trees and Beyond. 2009. Retrieved 31 January 2015. Available from:http://1 milliontreesandbeyond.com/one/index. php?option $=$ com_content $\&$ view $=$ article $\& i d=7 \&$ Itemid $=5$

Karun NC, Sridhar KR. 2013. Occurrence and distribution of Termitomyces (Basidiomycota, Agaricales) in the Western Ghats and on the West coast of India. Czech Mycology 65(2): 233-254. (Online Version, ISSN 1805-1421)

Klemm D. 2005. Cellulose: Fascinating Biopolymer and Sustainable Raw Material. Chem. Inform. Vol. 36 (Issue 36),

Koon TT. 1990. A Guide To Tropical Fungi. Omni-Theatre Signapore Science Centre. Singapore.

Læssøe T. 1998. Mushrooms. Dorling Kindersley Handbooks.

Lodge DJ, Ammiranti JF, O'dell TE, Mueller GM. 2004. Collecting and describing macrofungi In: Biodiversity of Fungi: Inventory Monitoring Methods (edsGM Mueller, GF Bills, MS Foster). Elsevier Academic Press, USA, $128-158$.

Luyon HAV, Salibay CC. 2007. Ectoparasites on Murid Rodents caught in Mts. Palay-Palay/MataasnaGulod National Park, Luzon Island, Philippines. Retrieved 31 January 2015. Available from: http://www.tm. mahidol.ac.th/seameo/2007-38-suppl-1/38suppl1-194.pdf

McKnight KH. 1999. A Field Guide to Mushrooms of North America. USA.

Quimio TH. 2001. Common Mushrooms of Mt. Makiling (Philippines). Museum of Natural History. University of the Philippines Los Baños.

Quimio TH. 1988. Illustrated Philippine Fungi Techguide Series No. 24. National Bookstore. Mandaluyong, Philippines. 
Redhead SA, Ryvarden L, Trappe JM, Watling R, Wu Q. 2007. Global Diversity and Distribution of Macrofungi. Biodiversity Conservation. 16, 37 - 48.

Reinking OA. 1921. Higher Basidiomycetes from the Philippines and their Hosts. Philippine Journal of Science. 479 - 480.

Reyes RG, Abella EA, Quimio TH. 2003. Wild macrofungi of CLSU. Journal of Tropical Biology 2, 8- 11.

Reyes RG, Eguchi F, Kalaw SP, Kikukawa T. 2009. Mushroom Growing in the Tropics: A Practical Guide. Nueva Ecija, Philippines. Central Luzon State University Press.

Swann E, Hibbett DS. 2007. Basidiomycota- The Club Fungi. Version 20 April 2007. Retrieved 31 January 2015. Available from: http://www.tolweb.org /Basidiomycota

Tadiosa ER, Agbayani ES, Agustin NT. 2011. Preliminary Study on the Macrofungi of Bazak-Baubo Watershed, Aurora Province, Central Luzon, Philippines. Asian Journal of Biodiversity Volume 2. pg. 149-171

Tadiosa ER, Arsenio JJ, Marasigan MC. 2007. Macroscopic fungal diversity of Mount Makulot, Cuenca, Batangas, Philippines. Journal of Nature Studies Vol 6, No. 1 and 2. 2007. pg. 111-124

Tadiosa ER. 1998. Some Noteworthy Species of Wood-rotting Fungi found in the Forested Hills of La Union Province. University of Sto. Tomas Journal of Graduate Research Volume 25. No. 2. pg. 55-58

Taylor JW, Spatafora J, Berbee M. 2006. Ascomycota. Sac Fungi. Version 09 October 2006 (under construction). Retrieved 20 January 2015. Available from: http://tolweb.org/Ascomycota/

Teodoro NG. 1937. An Enumeration of Philippine fungi. Comm. Phil. Dept. Agri., Manila. Tech. Bull. 4:1-568 